\title{
Consumption of Mineral Fertilizers in the Polish Agriculture - Trends and Directions of Changes
}

\author{
Arkadiusz Piwowar $^{1}$ (D)
}

Received: 11 October 2019/ Accepted: 7 June 2021/Published online: 29 June 2021

(C) The Author(s) 2021

\begin{abstract}
Balanced, rational fertilization determines high and valuable yields of crops. Polish agriculture has been considered traditional, pro-ecological, with relatively low consumption of agrochemicals for many decades. Transformations in the economic and social area, in particular Poland's accession to the European Union, have significantly changed this picture. This paper presents the results of the research on the trends in fertilizer consumption in the Polish agriculture. The main time range of the analyses covered the period of 2013-2017. The source materials used in the study were statistical data for the entire country and provinces, published by the Central Statistical Office (GUS), as well as results of empirical studies. According to analyses, the pressure associated with the increase in the use of mineral fertilizers in Poland is growing. In the economic year 2017/2018, the average consumption of mineral fertilizers in Poland was at a level of $141.6 \mathrm{~kg}$ NPK per hectare of agricultural lands and was higher by $39.2 \mathrm{~kg}$ than in the 2004/2005 season. The empirical studies were carried out in six randomly selected provinces in Poland. Total 1034 surveys completed by farmers were analysed. Comparative analyses were carried out using a multiple correspondence analysis (MPA). Based on the analysis performed, it can be stated that the direction of changes in the consumption of fertilizers depends on the area and economic size of the agricultural holding as well as on the district in which the agricultural holding is located. The article points out problems in the area of sustainable fertilizer consumption in Poland (high consumption of nitrogen fertilizers, low level of soil liming, etc.). Perspective directions of changes (precision agriculture, innovative fertilizers, increased farmers' awareness of nutrient efficiency and reduction of negative impact on the environment) were also summarized.
\end{abstract}

Keywords Agriculture · Correspondence analysis · Fertilization input · Poland · Sustainability

\section{Introduction}

Contemporary agricultural economics, considered from the perspective of the concept of sustainable development, subordinates the aspects of productivity and efficiency of management to capabilities of the natural environment $[12,18,26,27,38,45]$. Consumption of mineral fertilizers

Arkadiusz Piwowar

arkadiusz.piwowar@ue.wroc.pl

1 Department of Economics and Organization of Food Economy, Faculty of Economics and Finance, Wroclaw University of Economics and Business, ul. Komandorska 118/120, 53-345 Wrocław, Poland is an important element of analyses in the area of agricultural economics, both at the macro-, meso- and microeconomic levels $[20,30]$. The problem areas associated with the fertilization management in the agriculture and in agricultural holdings can be considered in technological, ecological and economic dimensions $[2,9,15,25,30]$. The technological dimension concerns the technical aspects of fertilizers as means of production and the equipment for their application. In the case of the ecological dimension, the threat to the natural environment and human health is worth mentioning. The excess of the unused nutrients gets into ground and surface water as well as to the atmosphere which carries nitrogen-containing compounds. In turn, the use of fertilizers significantly increases the agricultural production, which is associated 
with specific economic effects. The use of mineral fertilizers in the agriculture is an important element of the food security in all dimensions, i.e. with respect to the physical and economic availability of food as well as to the safety food [19, 46, 48, 52].

In the group of agrochemicals, crop yield enhancement agents (mainly fertilizers) and crop protection chemicals can be distinguished. Due to the functions of some components contained in agrochemicals and numerous possible interactions, there are also available agents that perform the functions of crop yield enhancement and protection. The formulation of the theory of the mineral nutrition of plants in mid-nineteen century contributed to the development of agricultural chemistry and scope for technology in the production of fertilizers. Previously, the commonly accepted theory and practice (theory of caries) assumed that humus, apart from water, was the most important source of nutrients for plants. Therefore, the use of fertilizers containing organic matter was mainly promoted. Currently, it is difficult to imagine efficient, high-volume agriculture without the use of mineral fertilizers. Mineral fertilization is one of the most important factors in the intensification of plant production. This factor has a significant impact on the productivity and quality of the harvested products $[4,5,22,29,43]$. At the same time, it is worth emphasizing that the irrational use of fertilizers (both in excess and in a too small amount) is ineffective. However, excessive doses of fertilizers in relation to the nutritional needs of plants and soil abundance are unreasonable both from the point of view of economics (waste) and protection of the natural environment [16]. The issue of external costs in relation to the irrationality in the area of fertilization management is the subject of many scientific studies. Similarly, a too low level of fertilization is unreasonable-it does not contribute to the utilization of the yielding potential of crops. Lower levels of fertilization, including the appropriate amount of macro- and microelements in doses of fertilizers, are also important $[17,41,44,47]$. The issue of irrationality also applies to chemical plant protection treatments [50].

In the different sources of the literature, there is a debate on the issues associated with intensity of fertilization and chemical protection of plants in the context of the goals of environmental protection and the nature conservation policy $[8,11,13,35,40,42]$. This is extremely important in Poland, because the scale of the crop production and the recorded levels of fertilization pose a potential threat from the point of view of environmental protection. The excessive fertilization with nitrogen and phosphorus at a low level of fertilization with lime is particularly dangerous [28]. The current consumption of mineral fertilizers in Poland is higher than in the majority of other European Union countries (Table 1). Data on consumption of mineral fertilizers in terms of pure ingredient included the breakdown on fertilizer nitrogen, phosphorus and potassium.

Current consumption of mineral fertilizers in Poland is very high, and only in the Benelux countries a higher level of mineral fertilization is recorded per 1 ha of UAA. Due to the cultivation area, the value of used mineral fertilizers in Poland is very high. Among EU countries, by far the highest value of fertilizers used in 2017 was recorded in France. Moreover, a high value was recorded in Germany, Spain, Poland, Italy and Great Britain (Fig. 1).

In the first years after Poland's accession to the EU (in 2004), a dynamic increase in the intensity of plant production was observed, mainly due to a significant increase in the use of mineral fertilizers [32]. From the point of view of the economics of agriculture and the protection of the natural environment, it is worth emphasizing that half of the agricultural lands in Poland is characterized by very high needs in the scope of liming. However, the level of liming in Poland has significantly decreased after Poland's accession to the European Union (from $91.5 \mathrm{~kg} \mathrm{CaO} / \mathrm{ha}$ of agricultural land in the season of $2014 / 2015$ to $55.1 \mathrm{~kg}$ $\mathrm{CaO} / \mathrm{ha}$ of agricultural land in the season of 2017/2018). It is also worth underlining that Poland is a leading European producer and exporter of mineral fertilizers, especially nitrogen fertilizers. In 2017, Poland produced a total of 2957 thousand tonnes of mineral fertilizers, calculated on the basis of the pure ingredient, including almost 2058 thousand tonnes of nitrogen fertilizers [51]. This is also associated with the issue of significant emissions of harmful substances [6, 34, 37].

The main purpose of this study was to determine the trends in the consumption of mineral fertilizers in Poland (basic nutrients: nitrogen, phosphorus, potassium). An additional goal was to identify the relationships between selected features of agricultural holdings and the direction of changes (increase, no change, decrease) in the scope of fertilization. This problem area concerns the little-known issues associated with fertilizer management, taking into account the organizational and economic features of agricultural holdings.

\section{Materials and Methods}

The study used both secondary data (mainly the data from official statistics, International Fertilizer Industry, Fertilizers Europe, Statistisches Bundesamt Deutschland) and the results of empirical research carried out in collaboration with Agricultural Advisory Centres in the period from November 2017 to March 2018 on a sample of 1101 agricultural holdings in Poland. The selection of the sample was random, and the research was carried out in six provinces of Poland (Lubelskie, Małopolskie, Mazowieckie, 
Table 1 The level of mineral fertilization in EU-28 countries in 2017/18 Source own elaboration based on data from International Fertilizer Industry, Fertilizers Europe, Statistisches Bundesamt Deutschland Industrieverband [21]

\begin{tabular}{|c|c|c|c|c|}
\hline \multirow{2}{*}{ Specification } & Nitrogen $(\mathrm{N})$ & Phosphorus $(\mathrm{P})$ & Potassium $(\mathrm{K})$ & NPK \\
\hline & \multicolumn{4}{|l|}{$[\mathrm{kg} / \mathrm{ha} \mathrm{AL}]$} \\
\hline Belgium/Luxembourg & 127 & 14 & 41 & 182 \\
\hline Denmark & 85 & 15 & 25 & 125 \\
\hline Germany & 90 & 14 & 25 & 129 \\
\hline Finland & 62 & 10 & 16 & 88 \\
\hline France & 77 & 15 & 15 & 107 \\
\hline Greece & 36 & 10 & 9 & 55 \\
\hline Great Britain & 59 & 11 & 16 & 86 \\
\hline Ireland & 85 & 23 & 31 & 139 \\
\hline Italy & 47 & 13 & 9 & 69 \\
\hline Netherlands & 104 & 7 & 32 & 143 \\
\hline Austria & 46 & 13 & 15 & 74 \\
\hline Portugal & 19 & 9 & 7 & 35 \\
\hline Sweden & 68 & 12 & 12 & 92 \\
\hline Spain & 45 & 16 & 15 & 76 \\
\hline Bulgaria & 79 & 18 & 7 & 104 \\
\hline Cyprus & 33 & 16 & 13 & 62 \\
\hline Estonia & 55 & 13 & 20 & 88 \\
\hline Croatia & 82 & 17 & 19 & 118 \\
\hline Latvia & 54 & 17 & 18 & 89 \\
\hline Lithuania & 58 & 16 & 20 & 94 \\
\hline Malta & no data & & & \\
\hline Poland & 81 & 23 & 39 & 143 \\
\hline Romania & 51 & 23 & 5 & 79 \\
\hline Slovakia & 65 & 14 & 10 & 89 \\
\hline Slovenia & 52 & 17 & 15 & 84 \\
\hline Czech Republic & 110 & 16 & 8 & 134 \\
\hline Hungary & 73 & 15 & 15 & 103 \\
\hline EU-15 & 64 & 14 & 17 & 95 \\
\hline EU-13 & 71 & 20 & 18 & 109 \\
\hline EU-28 & 66 & 15 & 17 & 98 \\
\hline
\end{tabular}

Opolskie, Pomorskie and Wielkopolskie). The research tool was thoroughly checked. Questions included in the questionnaire were formulated in a manner that would give the desired, valuable information. The questions in the questionnaire were formulated in a way that would allow providing reliable answers and obtaining objective and comparable data. Empirical research was conducted in 18 randomly selected counties (three from each province) (Fig. 2).

The total area of the agricultural holdings surveyed covered $31,819.75$ ha of agricultural lands, while the average area of an agricultural holding surveyed was $28.90 \mathrm{ha}$ of agricultural lands. The average age of respondents was 44 years old, while the largest share in the age structure had the group of respondents aged 40-49 (almost 30\% of the respondents). The participants in the surveys were mostly men $(81.8 \%$ of the respondents who indicated their gender), while the majority of all the respondents had secondary education (47\% of the respondents). Most respondents were characterized by a relatively considerable experience in agricultural activity. Over half of the respondents declared over 20-year work experience. Agricultural holdings with an area of agricultural lands of 5-9.99 ha were the predominant group in the surveys (i.e. $17.7 \%$ of all agricultural holdings surveyed). Nevertheless, larger agricultural holdings were also represented by a significant number of respondents (in total, the agricultural holdings with over 30 ha of agricultural lands accounted 


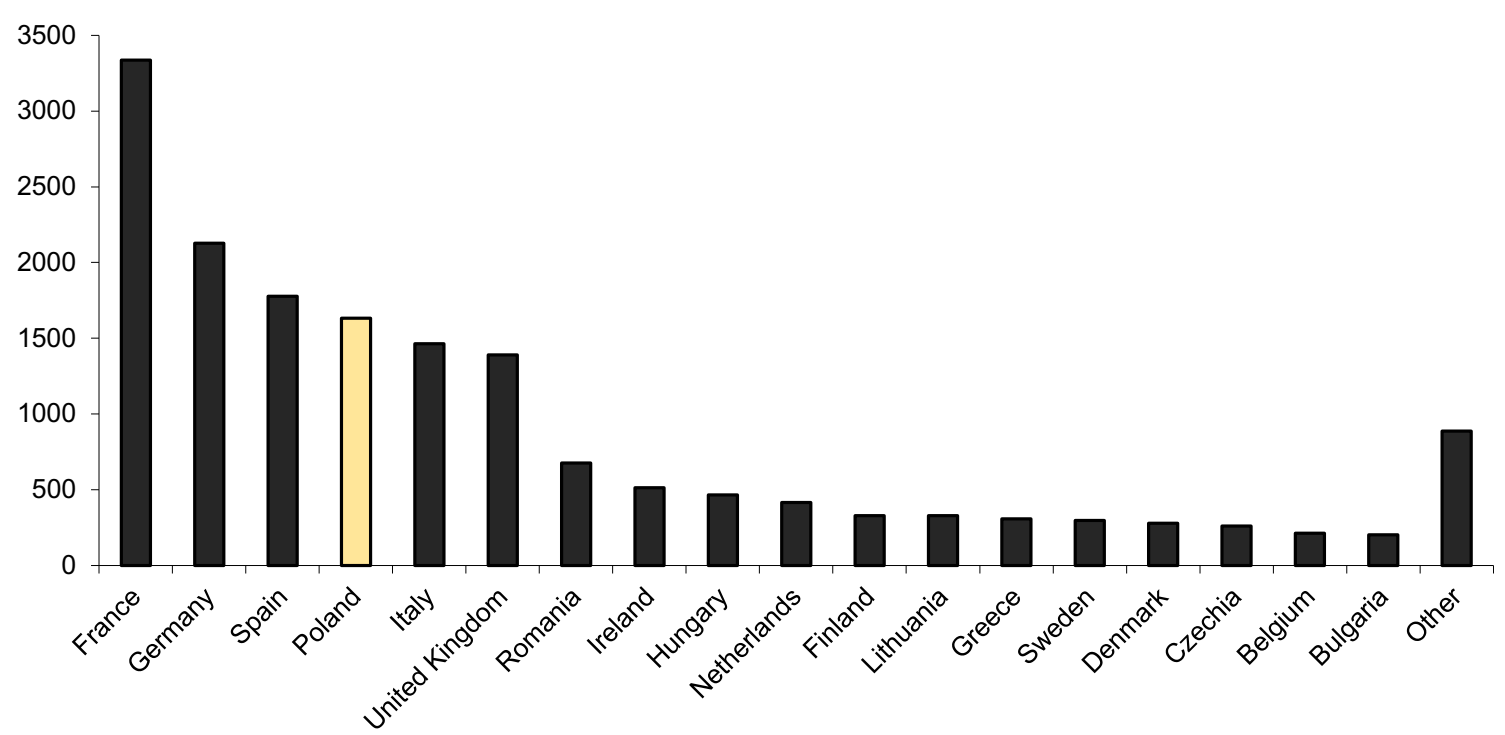

Fig. 1 The value of used fertilizers in selected EU countries in 2017 (million euros). Source own study based on Eurostat data [23]

Fig. 2 Spatial extent of the questionnaire surveys. Source own elaboration

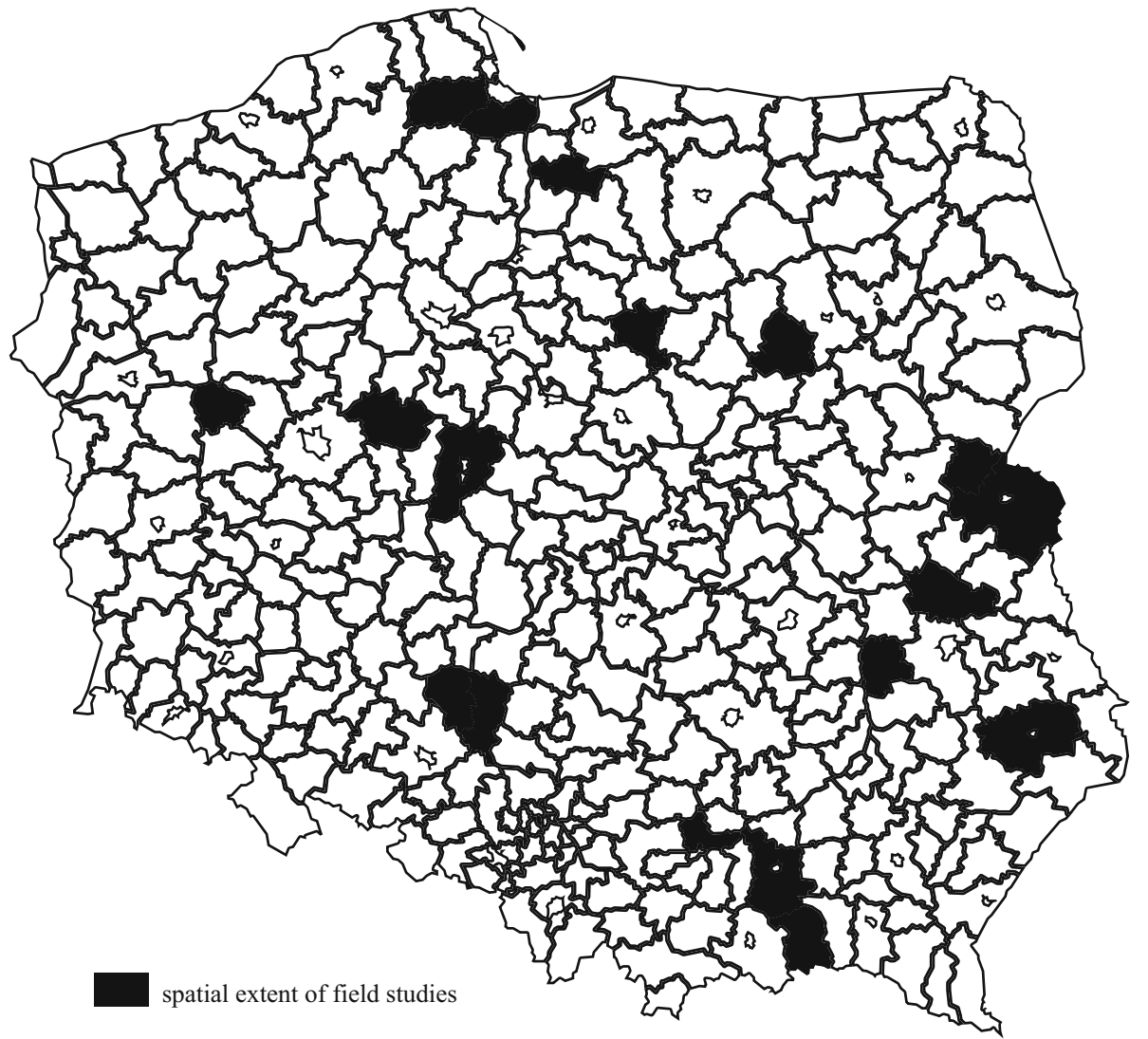

for $44.5 \%$ of the entire test sample). In turn, the economic size of the surveyed agricultural holdings most frequently was below EUR 10,000 (28.7\% of the agricultural holdings) [36]. In the randomly selected area, there was also a significant diversity in terms of fertilizer consumption (see Table 2). The main time range of the analyses concerned the period of 2013-2017. In order to provide a broader perspective on the issue of fertilizer consumption, statistical data for the period of 2004-2017 were also presented. The spatial extent of the analyses was characterised by a production potential that is relatively large on the scale of Poland and enables diversified agricultural production. 
Table 2 The level of the total mineral fertilization in Poland and the level by provinces in 2004, 2013 and 2017. Source own study based on statistical data [24]

\begin{tabular}{|c|c|c|c|c|c|}
\hline \multirow[t]{3}{*}{ Specification } & \multicolumn{3}{|c|}{ Consumption of mineral fertilizer } & \multicolumn{2}{|l|}{ Changes } \\
\hline & $\underline{2004}$ & 2013 & 2017 & 2013-2017 & 2004-2017 \\
\hline & \multicolumn{5}{|c|}{ [kg NPK/ha AL] } \\
\hline Dolnośląskie & 98.8 & 168.9 & 174.5 & 5.6 & 75.7 \\
\hline Kujawsko-pomorskie & 132.3 & 166.2 & 190.5 & 24.3 & 58.2 \\
\hline Lubelskie* & 99.8 & 140.4 & 163.3 & 22.9 & 63.5 \\
\hline Lubuskie & 115.5 & 98 & 112.8 & 14.8 & -2.7 \\
\hline Łódzkie & 117.9 & 135.6 & 132.7 & -2.9 & 14.8 \\
\hline Małopolskie* & 93.8 & 84.6 & 82.3 & -2.3 & -11.5 \\
\hline Mazowieckie* & 78.7 & 125.4 & 128.9 & 3.5 & 50.2 \\
\hline Opolskie* & 141.8 & 188 & 202.8 & 14.8 & 61.0 \\
\hline Podkarpackie & 66.1 & 80.1 & 85 & 4.9 & 18.9 \\
\hline Podlaskie & 87.1 & 115.7 & 124 & 8.3 & 36.9 \\
\hline Pomorskie* & 124.9 & 142.8 & 152.6 & 9.8 & 27.7 \\
\hline Śląskie & 101.5 & 138.3 & 124.9 & -13.4 & 23.4 \\
\hline Świętokrzyskie & 84.2 & 105.8 & 106 & 0.2 & 21.8 \\
\hline Warmińsko-mazurskie & 90.3 & 100.2 & 113.6 & 13.4 & 23.3 \\
\hline Wielkopolskie* & 114.6 & 158.2 & 170.4 & 12.2 & 55.8 \\
\hline Zachodniopomorskie & 117.8 & 117.3 & 115.5 & -1.8 & -2.3 \\
\hline POLAND & 102.4 & 132.9 & 141.6 & 8.7 & 39.2 \\
\hline
\end{tabular}

*provinces, where empirical studies were carried out

The character of the analyses required conducting own research (no data in the official statistics). This was important for acquiring new knowledge about the behaviour of agricultural producers who used fertilizers (analysis of the impact of the area of an agricultural holding, its economic size class and geographical location on the direction of changes in the consumption of fertilizers). The respondents indicated in the questionnaire survey, inter alia, changes in the mineral fertilization over a period of 5 years (i.e. 2013-2017). The results of the research presented in this paper are part of the research carried out under the grant awarded by the National Science Centre in Poland.

This paper presents the application of the correspondence analysis, a specialized data mining method, for determining the relationships between variables or objects [3]. The methodology of the correspondence analysis is based on the $\chi^{2}$ test of independence [10, 31, 49]. Analyses based on Burt Table (symmetric block matrix) were performed within the study in order to investigate the cooccurrence of categories of many variables. Diagonal matrices (they include the number of occurrences of the category of features) are placed on the main diagonal of this matrix, while the contingency tables for each pair of the tested variables are placed outside the diagonal. The use of the correspondence analysis enabled identification of the co-occurrence of categories of variables. The correspondence analysis for the needs of this study was carried out with the use of the STATISTICA 13.3 computer programme. A method of descriptive statistics was used to process the results of the analyses on the basis of secondary data.

\section{Results and Discussion}

In recent years, in the Polish agriculture, there has been a relatively high level of consumption of mineral fertilizers (Fig. 3) and a significant spatial differentiation of this level (Table 2).

In the economic year 2017/2018, the average consumption of mineral fertilizers in Poland was at a level of $141.6 \mathrm{~kg}$ NPK per hectare of agricultural lands ${ }^{1}$ and was higher by $39.2 \mathrm{~kg}$ than in the 2004/2005 season. In turn, in the period of 2013-2017, the average consumption of mineral fertilizers in Poland increased by $8.7 \mathrm{~kg}$. Nitrogen fertilization clearly predominates in the structure of fertilization in Poland. In the 2017/2018 season, the share of nitrogen fertilization in the structure of NPK fertilization

\footnotetext{
${ }^{1}$ IFA data on NPK consumption slightly differ from GUS data (see Table 1).
} 


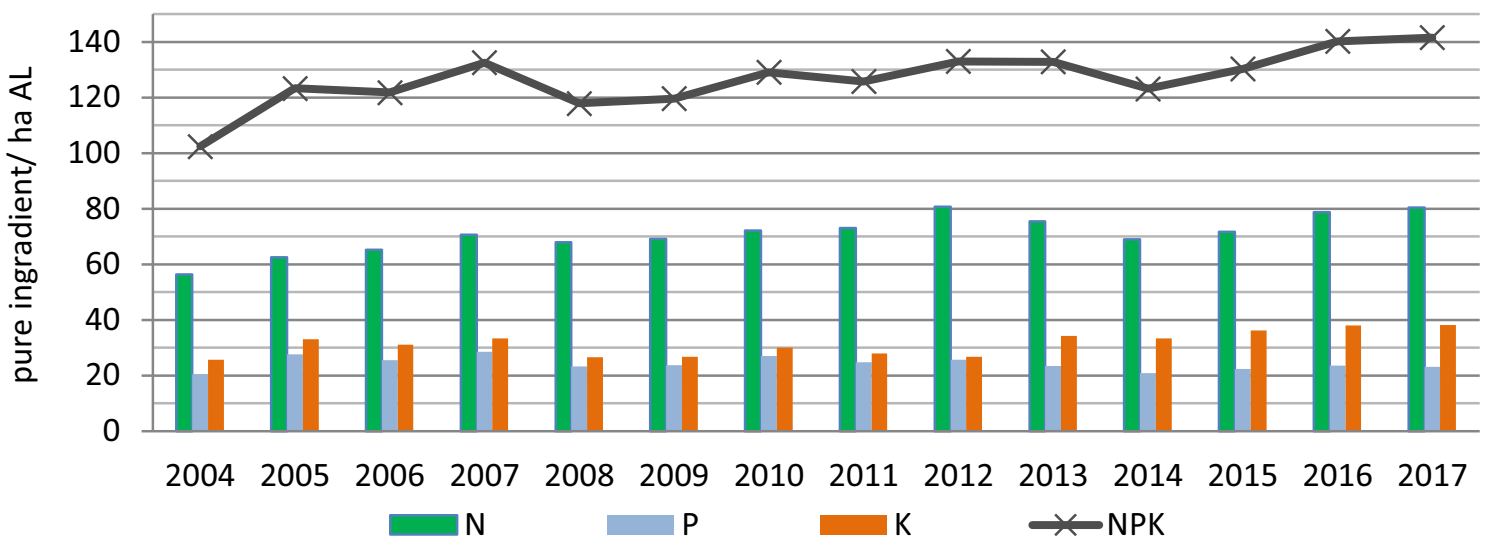

Fig. 3 The level of mineral fertilization in Poland in 2004-2017. Source own study based on [39]

was $57 \%$. In 2004-2017, the share of nitrogen fertilization in the total structure of fertilization increased slightly (by 1.8 percentage point).

There are a lot of factors affecting the level of mineral fertilization and its diversification over time. Important factors include economic factors (current and projected incomes of farmers, price relations between purchase prices of crops and purchase prices of means of agricultural production, etc.), natural factors (nutritional requirements of plants, the content of nutrients in soils, etc.) as well as organizational factors (technologies and techniques used in agricultural production, skills, knowledge, etc.). In Poland, there are significant differences not only in the level of fertilization over time, but also in the spatial extent (Table. 2).

The consumption of mineral fertilizers in Poland is characterized by a considerable regional differentiation, which results as diversity in nature like soil and climatic conditions from the diversity of natural conditions as diversity in nature like soil and climatic conditions as well as from organizational and economic factors. The highest level of fertilization in the 2017/2018 season was in Opolskie, Dolnośląskie, Kujawsko-Pomorskie and Wielkopolskie Provinces, while the lowest one - in Podkarpackie and Małopolskie Provinces. In the analysed period, the classification of provinces in terms of the extent of fertilization changed to a slight extent. In 2004-2017, a reduction in the level of fertilization was recorded only in 3 out of 16 provinces in Poland (in the Małopolskie, Lubuskie and Zachodniopomorskie Provinces). The highest increase in the level of fertilization in 2004-2017 was recorded in Dolnośląskie Province (by $75.7 \mathrm{~kg} \mathrm{NPK} / \mathrm{ha}$ of agricultural lands). In turn, in the period of 2013-2017, a decrease in the level of fertilization was recorded in the following provinces: Śląskie (by $13.4 \mathrm{~kg}$ ); Łódzkie (by $2.9 \mathrm{~kg}$ ), Małopolskie (by $2.3 \mathrm{~kg}$ ) and Zachodniopomorskie (by $1.8 \mathrm{~kg}$ ). In the analysed years, the regional differentiation in the level of fertilization in Poland deepened. The coefficients of variation in 2004, 2013 and 2017 were as follows: $19.8 \% ; 24.3 \%$ and $26.3 \%$, respectively.

The results summarized in this work are against the background of general data from official statistics. In official statistics, there is no information on the consumption of fertilizers in agriculture taking into account the area of agricultural holdings, economic size class, etc. It is therefore important to conduct primary research in this scope. As mentioned in the description of the methodology, such data were collected in the course of the research work concerning the low-carbon agriculture in Poland.

In this work, total 1101 survey questionnaires were collected and out of which, 1034 questionnaires were accepted for further analysis in the thematic scope of this study. The questionnaires that prevented creation of the Burt matrix and carrying out the correspondence analysis were rejected (incomplete information about the attributes of the agricultural holding). In the survey participation, 631 farmers declared that the level of fertilization did not change in the investigated period, 207 respondents declared an increase in the level of fertilization, while 196 - a decrease.

The results concerning the change in the consumption of mineral fertilizers declared by the farmers have inspired a study on the relationship between features and attributes of an agricultural holding. Four variables were selected for the detailed analyses: direction of changes in the level of fertilizer consumption, area of agricultural lands, economic size class of agricultural holding and district in which agricultural holding was located. The numerical data for the analysis were placed in the form of $20 \times 20$ Burt matrix. In order to determine the existence of the dependence and its strength, the values of the $\chi^{2}$ statistics and the mean square contingency were calculated (Table 3 ).

For all pairs of features, the critical values read from the chi-squared distribution tables at a given level of 
Table 3 Statistics values $\chi^{2}$, critical values $\chi_{\alpha=0.01}^{2}$ (in parentheses) and mean square contingency $\varphi^{2}$ for the following features: fertilization, arable land area, economics size of agriculture holding and district. Source own study based on questionnaire surveys

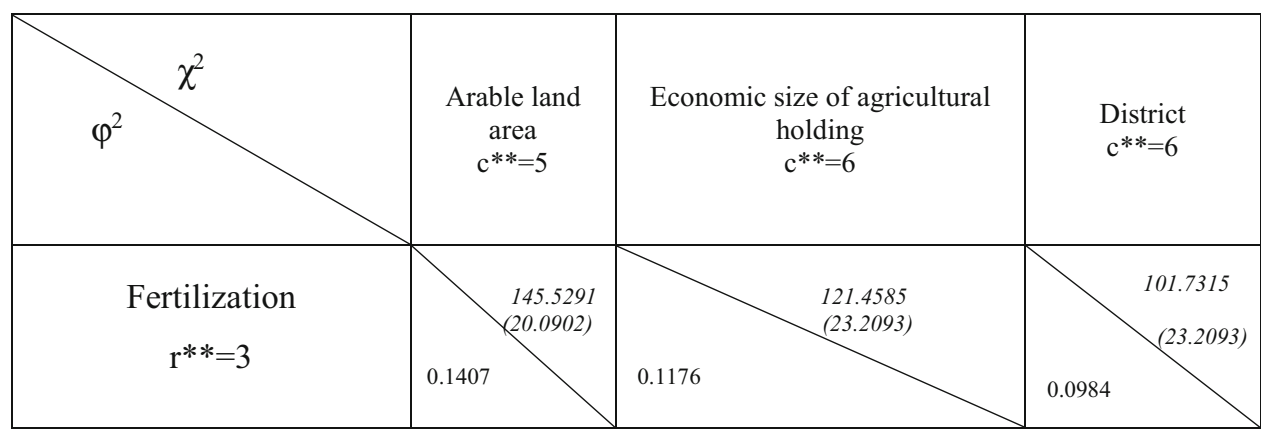

*critical values $\chi^{2} \alpha=0.01$ read from the tables for ( $\left.\mathrm{r}-1\right) \mathrm{x}$ (c-1) degrees of freedom

$* *$ number of rows and columns of the variables analysed

significance are lower than the $\chi^{2}$ statistics calculated. This means that the hypothesis on the independence of the examined features should be rejected and that the direction of changes in the level of consumption of fertilizers depends on other variables like area of agricultural holding, economic size class and district in which agricultural holding is located. In addition, the correspondence analysis carried out in the further part of the study allowed defining these relationships more precisely. Figure 4 presents (in three-dimensional space) the result of the correspondence analysis of the declared direction of changes in the level of consumption of fertilizers in 2013-2017 with the analysed features of agricultural holdings.

When analysing the distribution of points in Fig. 4, it can be noticed that near the centre of the system there are points representing a lack of changes in the level of consumption of fertilizers (E2). This is a profile closest to the average, with which most profiles of districts (P1, P2, P6) correspond. The analysis of correspondence showed that there was the co-occurrence between variables E3 (decrease in fertilizer consumption in 2013-2017) and S4 and U3. This means that there was a convergence between the reduction in the consumption of fertilizers and the agricultural holdings of a relatively average size (both in terms of area and economic class). The location of the E1 variable proves that it is difficult to precisely determine the features of agricultural holdings, with increased level of fertilization in internal and external features like area of agricultural holding, economic size class and geographical location, respectively. Nevertheless, the proximity of the location of the points coding small agricultural holdings (U1, U2, S1) and the E3 point allows concluding that the increase in the intensity concerns mainly these agricultural holdings. An increase in the chemicalization of agriculture, contrary to common opinions, also concerns small, economically weaker agricultural holdings. Nevertheless, high doses of mineral fertilizers are often used both in very small agricultural holdings and in very large ones in terms of economic power. This raises questions about the rationality of the activities in the area of fertilization management, which is an essential element in the evaluation of the sustainability of individual agricultural holdings. It is necessary to undertake further, comprehensive research on this phenomenon, taking into account the fertilizer balance and the organic matter balance in individual agricultural holdings in Poland.

Changes in the use of mineral fertilizers take place as a result of market, legal and technological changes. The main source of supply for Polish farmers with fertilizers is the domestic chemical industry. It is worth emphasizing that Poland is a significant producer and exporter of mineral, mainly nitrogenous fertilizers in Europe [51]. In the Polish fertilizer industry, consolidation and deepened cooperation processes were observed in the analysed years. The effect of these activities was, inter alia, establishment of the Azoty Group (a capital group that is currently one of the leaders in the production of nitrogen and compound fertilizers in the European Union). Enterprises producing mineral fertilizers are implementing new technological solutions and producing innovative products with the aim of increasing the efficiency of fertilization and minimizing external environmental costs. Consolidation also translates into an improvement in the distribution of fertilizers. There are many innovative companies on the Polish market in the studied area, which produce, inter alia, fertilizers for foliar feeding $[34,51]$. The increase in fertilization in Poland in recent years is also associated with an improvement in the income situation of farmers, which was mainly due to direct payments under the Common Agricultural Policy. The increase in prices on agricultural markets resulted in higher income of agricultural producers, which promoted investing in means of production, including fertilizers 
Fig. 4 Graphic presentation of the results of the correspondence analysis of the direction of changes in the level of consumption of fertilizers with the analysed features of agricultural holdings. Source own study based on questionnaire surveys

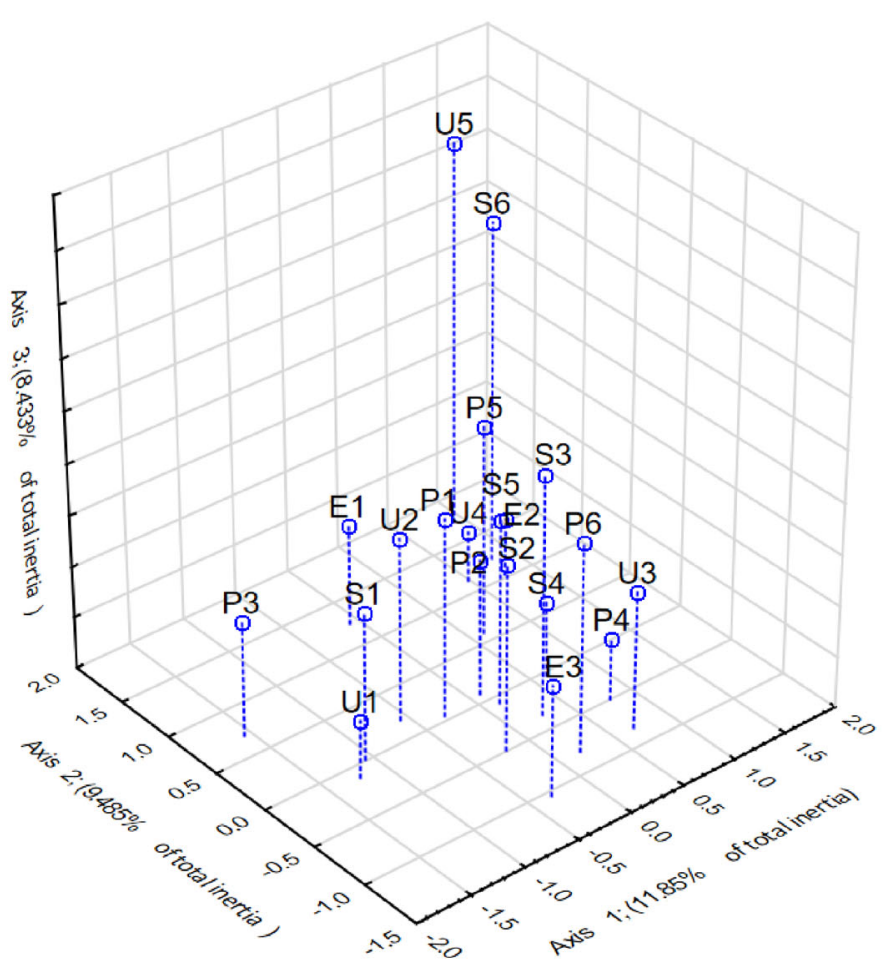

\begin{tabular}{|c|c|c|c|c|c|c|c|c|c|c|c|c|c|c|c|c|c|c|c|c|}
\hline \multirow[b]{2}{*}{ Variable } & \multicolumn{3}{|c|}{ Fertilization } & \multicolumn{5}{|c|}{ Arable land area (ha) } & \multicolumn{6}{|c|}{ Economic size of agricultural holding (SO) } & \multicolumn{6}{|c|}{ District } \\
\hline & 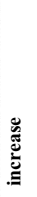 & 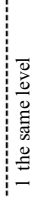 & 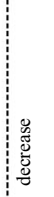 & 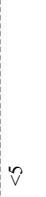 & $\begin{array}{l}\sigma \\
\stackrel{\sigma}{\prime} \\
\dot{n}\end{array}$ & $\begin{array}{l}\curvearrowright \\
\text { ఫे } \\
\text { ปे }\end{array}$ & $\begin{array}{l}\hat{\partial} \\
\text { aे } \\
\hat{i} \\
\text { in }\end{array}$ & $\frac{8}{\wedge}$ & 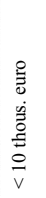 & 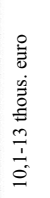 & 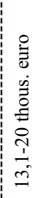 & 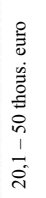 & 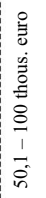 & 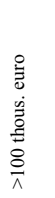 & 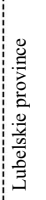 & 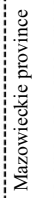 & 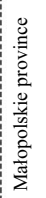 & 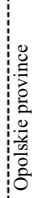 & 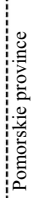 & 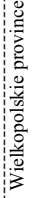 \\
\hline Symbol & E1 & $\mathrm{E} 2$ & $\mathrm{E} 3$ & $\mathrm{U} 1$ & $\mathrm{U} 2$ & $\mathrm{U} 3$ & $\mathrm{U} 4$ & $\mathrm{U} 5$ & S1 & S2 & S3 & S4 & S5 & S6 & $\mathrm{P} 1$ & $\mathrm{P} 2$ & $\mathrm{P} 3$ & $\mathrm{P} 4$ & $\mathrm{P} 5$ & $\mathrm{P} 6$ \\
\hline
\end{tabular}

$[32,33]$. In the investigated subject area, in addition to data from official statistics, there also used empirical data concerning the behaviours of farmers in agricultural practices and their transformation. According to the research, the level of mineral fertilization in Poland is increasing and currently is one of the largest in the European Union. At the same time, there is a significant, deepening diversification in the spatial scope (across provinces). Nitrogen fertilization clearly predominates in the structure of fertilization. The results of analyses based on the secondary data are clear. It is necessary to adopt and implement programmes and policies in the scope of the investigation. Sustainable fertilization and minimization of possible losses in the natural environment (e.g. eutrophication) are important from the point of view of human and animal health. Modifications of the existing agricultural practices that will limit the excessive use of fertilizers are necessary.
These practices should be optimized in relation to organizational and natural conditions.

Sustainable fertilization based on the rational use of mineral fertilizers is a necessity and an important element of sustainable development of agriculture in Poland. Thanks to technological and product innovations in the fertilizer industry, farmers can buy high-quality products for the controlled release of nutrients. The potential for innovative products in the area of fertilizers is high, not only from an economic but also from a social point of view [1]. Rational fertilization, in accordance with the principles of sustainable development, should balance the nutritional needs of plants and at the same time not create high reserves of nutrients in the soil. An important element which guarantees this state of affairs in Poland is the implementation of solutions in the field of precision farming. It is essential to use appropriate technical equipment, supported by ICT. It is also necessary to improve 
other elements of balanced fertilization-in the area of optimal sizes of individual nutrients, suitably adapted forms of fertilizers to soil and weather conditions, optimal dates of fertilizer as the appropriate way by soil and foliar applications. In agricultural practice, this requires investment in technical infrastructure and development of agricultural consulting in the area of fertilization. A high and increasing level of mineral fertilization in Poland raises the need for training agricultural producers in the area of sustainable development, including the dissemination of knowledge in the field of production and environmental effects of the use of mineral fertilizers [7, 14]. Soil acidification in Poland and a drastic decrease in their liming are another problem in the field of sustainable nutrient management in agriculture.

\section{Conclusions}

In this study, an attempt was made to apply the method of correspondence analysis for the identification of relationships between the direction of changes in the level of fertilization and the selected attributes of agricultural holdings. The use of the correspondence analysis allowed identifying the diversity and co-occurrences of categories of variables. The empirical studies show that the direction of changes in the consumption of fertilizers depends on the area and economic size of the agricultural holding as well as on the district in which the agricultural holding is located. The strength of the relationship between the features was the greatest with regard to the direction of changes in the amount of fertilization and the size of agricultural land. On the other hands, the lowest strength of the relationship among the studied variables was in relation to the direction of changes in the fertilization amount and the location of farms (district). The conducted correspondence analysis showed statistically significant relationships between the increased fertilization level and relatively small farms. The conclusions from the research are both of cognitive and utilitarian nature. There is a need to modify the programmes in the scope of preparation of fertilization plans and to extend this requirement also to smaller agricultural holdings in Poland. Currently, the requirement to prepare a nitrogen fertilization plan (from 1 January 2019) applies to large agricultural holdings-over 100 ha of the total area of agricultural lands or over 50 ha of intensive cultivation. Agricultural holdings depend not only on the area but also on the scale of animal production and the intensity of crop production complies with compulsory practices. Smaller agricultural holdings only have to keep records of agrotechnical treatments. In the light of the data presented in this paper, it is necessary to make changes in the environmental policy and to pay more attention to the environmental sustainability of agricultural holdings in Poland, especially in Opolskie and Zachodniopomorskie provinces with a high level of fertilization.

Funding This study was conducted and financed in the framework of the research project "The state and prospects of the development of low-carbon agriculture in Poland and the behaviour of agricultural producers", granted by the National Science Centre in Poland, programme SONATA, grant No. 2016/21/D/HS4/00087.

Open Access This article is licensed under a Creative Commons Attribution 4.0 International License, which permits use, sharing, adaptation, distribution and reproduction in any medium or format, as long as you give appropriate credit to the original author(s) and the source, provide a link to the Creative Commons licence, and indicate if changes were made. The images or other third party material in this article are included in the article's Creative Commons licence, unless indicated otherwise in a credit line to the material. If material is not included in the article's Creative Commons licence and your intended use is not permitted by statutory regulation or exceeds the permitted use, you will need to obtain permission directly from the copyright holder. To view a copy of this licence, visit http://creative commons.org/licenses/by/4.0/.

\section{References}

1. Balawejder M, Szostek M, Gorzelany J, Antos P, Witek G, Matłok N (2020) A Study on the Potential Fertilization Effects of Microgranule Fertilizer Based on the Protein and Calcined Bones in Maize Cultivation. Sustainability 12(4):1343

2. Basso B, Dumont B, Cammarano D, Pezzuolo A, Marinello F, Sartori L (2016) Environmental and economic benefits of variable rate nitrogen fertilization in a nitrate vulnerable zone. Sci Total Environ 545:227-235

3. Berezka K, Kovalchuk O (2018) Correspondence analysis as a tool for computer modeling of sustainable development. Econometrics 22(4):9-23

4. Bożek KS, Winnicki T, Żuk-Gołaszewska K (2019) The effects of seeding rate, mineral fertilization and a growth regulator on the economic and energy efficiency of durum wheat production. Acta Scientiarum Polonorum seria Agricultura 18(3):133-144

5. Černý J, Balík J, Kulhánek M, Nedvěd V (2012) Mineral and organic fertilization efficiency in long-term stationary experiments. Plant Soil Environ 56(1):28-36

6. Chojnacka K, Kowalski Z, Kulczycka J, Dmytryk A, Górecki H, Ligas B, Gramza M (2019) Carbon footprint of fertilizer technologies. J Environ Manage 231:962-967

7. Drangert JO, Kiełbasa B, Ulen B, Tonderski KS, Tonderski A (2017) Generating applicable environmental knowledge among farmers: experiences from two regions in Poland. Agroecol Sustain Food Syst 41(6):671-690

8. Drinkwater LE, Snapp SS (2007) Nutrients in agroecosystems: rethinking the management paradigm. Adv Agron 92:163-186

9. Eberhardt M, Vollrath D (2018) The effect of agricultural technology on the speed of development. World Dev 109:483-496

10. Fithian W, Josse J (2017) Multiple correspondence analysis and the multilogit bilinear model. J Multivar Anal 157:87-102

11. Frische T, Egerer S, Matezki S, Pickl C, Wogram J (2018) 5-Point programme for sustainable plant protection. Environ Sci Eur 30(1):8 
12. Guo Z, Wan S, Hua K, Yin Y, Chu H, Wang D, Guo X (2020) Fertilization regime has a greater effect on soil microbial community structure than crop rotation and growth stage in an agroecosystem. Appl Soil Ecol 149:103510

13. Górski J, Dragon K, Kaczmarek PMJ (2019) Nitrate pollution in the Warta River (Poland) between 1958 and 2016: trends and causes. Environ Sci Pollut Res 26(3):2038-2046

14. Grzebisz W, Diatta J, Hardter R, Cyna K (2010) Fertilizer consumption patterns in Central European countries-effect on actual yield development trends in 1986-2005 years-a comparative study of the Czech Republic and Poland. Journal of Central European Agriculture 11(1):73-82

15. Han HY, Zhao LG (2009) Farmers' character and behavior of fertilizer application-evidence from a survey of Xinxiang County, Henan Province. China Agricultural Sciences in China 8(10):1238-1245

16. Hasler K, Olfs HW, Omta O, Bröring S (2017) Drivers for the Adoption of Different Eco-Innovation Types in the Fertilizer Sector: A Review. Sustainability 9:2216

17. Herencia JF, Ruiz-Porras JC, Melero S, Garcia-Galavis PA, Morillo E, Maqueda C (2007) Comparison between organic and mineral fertilization for soil fertility levels, crop macronutrient concentrations, and yield. Agron J 99(4):973-983

18. Horrigan L, Lawrence RS, Walker P (2002) How sustainable agriculture can address the environmental and human health harms of industrial agriculture. Environ Health Perspect 110:445-456

19. Huang J, Xu CC, Ridoutt BG, Wang XC, Ren A (2017) Nitrogen and phosphorus losses and eutrophication potential associated with fertilizer application to cropland in China. J Clean Prod 159:171-179

20. Ierna A, Mauromicale G (2019) Sustainable and Profitable Nitrogen Fertilization Management of Potato. Agronomy $9(10): 582$

21. Industrieverband Agrar (2019) Wichtige Zahlen 2018-2019. Düngemittel, Produktion, Markt, Landwirtschaft. Available at: https://www.iva.de/publikationen. Accessed 20 Feb 2020

22. Izydorczyk G, Sienkiewicz-Cholewa U, Baśladyńska S, Kocek D, Mironiuk M, Chojnacka K (2020) New environmentally friendly bio-based micronutrient fertilizer by biosorption: From laboratory studies to the field. Sci Total Environ 710:136061

23. https://ec.europa.eu/eurostat/data/database. Accessed $22 \mathrm{Feb}$ 2020

24. https://stat.gov.pl/obszary-tematyczne/rolnictwo-lesnictwo/ rolnictwo/srodki-produkcji-w-rolnictwie-w-roku-gospodarczym20162017,6,14.html?pdf $=1$. Accessed 4 Aug 2019

25. Kamal AM, Whalen JK (2019). Agroenvironmental protection and sustainable agriculture. Bioremed Agric Soils 38(71.6):30

26. Kling CL, Segerson K, Shogren JF (2010) Environmental economics: how agricultural economists helped advance the field. Am J Agr Econ 92(2):487-505

27. Lanz B, Dietz S, Swanson T (2018) The expansion of modern agriculture and global biodiversity decline: An integrated assessment. Ecol Econ 144:260-277

28. Lawniczak AE, Zbierska J, Nowak B, Achtenberg K, Grześkowiak A, Kanas K (2016) Impact of agriculture and land use on nitrate contamination in groundwater and running waters in central-west Poland. Environ Monit Assess 188(3):172

29. Lubkowski K (2016) Environmental impact of fertilizer use and slow release of mineral nutrients as a response to this challenge. Pol J Chem Technol 18(1):72-79

30. McArthur JW, McCord GC (2017) Fertilizing growth: Agricultural inputs and their effects in economic development. J Dev Econ 127:133-152
31. Parchomenko A, Nelen D, Gillabel J, Rechberger H (2019) Measuring the circular economy-A Multiple Correspondence Analysis of 63 metrics. J Clean Prod 210:200-216

32. Piwowar A (2013) Mineral fertilization in the chosen Lower Silesian districts. J Cent Eur Agric 14(2):316-328 [In Polish]

33. Piwowar A (2013) Supply, demand and prices of phosphorus fertilizers market in Poland in 2004-2009. J Cent Eur Agric 14(2):329-340 [In Polish]

34. Piwowar A (2017) Ekoinnowacje w zakresie agrochemikaliów i ich wpływ na rozwój niskoemisyjnej gospodarki. Przem Chem 96(8):1625-1627 [In Polish]

35. Piwowar A (2019) Low carbon agriculture in Poland - theoretical and practical challenges. Pol J Environ Stud 28(4):2785-2792

36. Piwowar A (2020) Attitudes and opinions of farmers in the context of environmental protection in rural areas in Poland. Environ Monit Assess 192:180

37. Piwowar A, Dzikuć M (2017) LCA w produkcji agrochemikaliów. Procedura, kategorie wpływu, możliwości wykorzystania. Przem Chem 96(2):271-274 [In Polish]

38. Rose DC, Sutherland WJ, Barnes AP, Borthwick F, Ffoulkes C, Hall C, Moorby JM, Nicholas-Davies P, Twining S, Dicks LV (2019) Integrated farm management for sustainable agriculture: Lessons for knowledge exchange and policy. Land Use Policy 81:834-842

39. Rynek środków produkcji dla rolnictwa (2019) Analizy Rynkowe 36:16 [In Polish]

40. Shrestha S, Ciaian P, Himics M, Van Doorslaer B (2013) Impacts of climate change on EU agriculture. Review of Agricultural and Applied Economics 16:24-39

41. Singh R, Singh P, Singh H, Raghubanshi AS (2019) Impact of sole and combined application of biochar, organic and chemical fertilizers on wheat crop yield and water productivity in a dry tropical agro-ecosystem. Biochar 1(2):229-235

42. Snyder CS, Bruulsema TW, Jensen TL, Fixen PE (2009) Review of greenhouse gas emissions from crop production systems and fertilizer management effects. Agr Ecosyst Environ 133(3-4):247-266

43. Taliman NA, Dong Q, Echigo K, Raboy V, Saneoka H (2019) Effect of phosphorus fertilization on the growth, photosynthesis, nitrogen fixation, mineral accumulation, seed yield, and seed quality of a soybean low-phytate line. Plants 8(5):119

44. Teodorescu M, Lungu A, Stanescu PO (2009) Preparation and properties of novel slow-release NPK agrochemical formulations based on poly (acrylic acid) hydrogels and liquid fertilizers. Ind Eng Chem Res 48(14):6527-6534

45. Tilman D, Cassman KG, Matson PA, Naylor R, Polasky S (2002) Agricultural sustainability and intensive production practices. Nature 418(6898):671

46. Tóth G, Guicharnaud RA, Tóth B, Hermann T (2014) Phosphorus levels in croplands of the European Union with implications for $\mathrm{P}$ fertilizer use. Eur J Agron 55:42-52

47. Wang Z, Hassan MU, Nadeem F, Wu L, Zhang F, Li X (2020) Magnesium Fertilization Improves Crop Yield in Most Production Systems: A Meta-Analysis. Front Plant Sci 10:1727

48. Weikard HP (2016) Phosphorus recycling and food security in the long run: a conceptual modelling approach. Food Security 8(2):405-414

49. Van de Velden M, van den Heuvel W, Galy H, Groenen PJ (2020) Retrieving a contingency table from a correspondence analysis solution. Eur J Oper Res 283(2):541-548

50. Van Meter RJ, Adelizzi R, Glinski DA, Henderson WM (2019) Agrochemical Mixtures and Amphibians: The Combined Effects of Pesticides and Fertilizer on Stress, Acetylcholinesterase Activity, and Bioaccumulation in a Terrestrial Environment. Environ Toxicol Chem 38(5):1052-1061 
51. Zalewski A, Piwowar A (2018) Światowy rynek nawozów min-

Publisher's Note Springer Nature remains neutral with regard to eralnych z uwzględnieniem zmian cen surowców i bezpośrednich nośników energii. Wyd. IERiGŻ-PIB, Warszawa 2018, ISBN jurisdictional claims in published maps and institutional affiliations. 978-83-7658-758-5 [In Polish]

52. Zhu ZL, Jin JY (2013) Fertilizer use and food security in China. Plant Nutrition and Fertilizer Science 19(2):259-273 